Kaspullah, Suriadi /_Ta'dib: Jurnal Pendidikan Islam, Vol. 9 No. 1 (2020) 31-41

ISSN 1411-8173 | E-ISSN 2528-5092

https://ejournal.unisba.ac.id/index.php/tadib/article/view/6010

\title{
GLOBALIZATION IN ISLAMIC EDUCATION (INTERNALIZATION STRATEGY OF LOCAL VALUES IN ISLAMIC EDUCATION IN THE ERA OF GLOBALIZATION)
}

\author{
Kaspullah $^{1}$, Suriadi ${ }^{2}$ \\ 1,2Institut Agama Islam Sultan Muhammad Syafiuddin Sambas \\ Email: 1kaspullahbangde@gmail.com, ${ }^{2}$ suriadisambas@gmail.com \\ DOI: https://doi.org/10.29313/tjpi.v9i1.6010 \\ Submitted: May 05th, 2020. Approved: June 20th, 2020. Published: June 20th, 2020
}

\begin{abstract}
This article is about Globalization in Islamic Education (Internalization of Local Wisdom Values Strategies in Islamic Education in the Era of Globalization). This study aims to describe the internalization of the value of local wisdom in Islamic education. The research approach uses this type of library research. The research approach is the analysis of text and information related to the study. This research is focused on how the process of internalizing the value of local wisdom in Islamic education. The results of the analysis concluded that wisdom is an alternative that seeks to maintain and preserve the noble values of the nation's culture in it including strengthening Islamic education. The strategy of internalizing Indonesian local wisdom can be implemented through the learning process at school. This can be implemented through learning activities. One of them is integrating it with Islamic education learning. In practice, it requires the synergy of three main elements in education. This element can be carried out through the three pillars of education namely in formal education, formal education, and non-formal education. It is also necessary to empower community leaders, traditional leaders, religious leaders, youth leaders as well as models of exemplary behavior in maintaining and preserving the values of local wisdom in daily life.
\end{abstract}

Keywords: Globalization; Education; Strategy; Internalization; V alues.

\begin{abstract}
Abstrak
Artikel ini mambahas tentang Globalisasi Dalam Pendidikan Islam (Strategi Internalisasi Nilai-Nilai Kearifan Lokal dalam Pendidikan Islam Di Era Globalisasi). Penelitian ini bertujuan untuk mendeskripsikan internalisasi nilai kearifan lokal dalam pendidikan Islam. Adapun pendektan Penelitian ini menggunakan jenis penelitian kepustakaan (library research). Pendekatan penelitian adalah analisis teks dan informasi yang terkait dengan kajian. Penelitian ini difokuskan pada bagaimana proses internalisasi nilai kearifan lokal dalam pendidikan Islam. Hasil analisis menyimpulkan bahwa kearifan merupakan salah satu alternatif yang berupaya mempertahankan dan melestarikan nilai-nilai lubur budaya bangsa di dalamnya termasuk memperkuat pendidikan Islam. Strategi internalisasi kearifan lokal Indonesia dapat dilaksanakan melalui proses pembelajaran di sekolah. Hal tersebut dapat dilaksanakan melalui kegiatan pembelajaran. Salah satunya adalah mengintegrasikannya dengan pembelajaran pendidikan Islam. Dalam praktinya memerlukan sinergi dari tiga unsur utama dalam pendidikan. Unsur tersebut dapat dilakukan melalui tiga pilar pendidikan yakni pendidik an in formal, pendidikan formal, dan pendidikan non formal. Perlu juga dilakukan pemberdayaan tokoh masyarakat, tokoh adat, tokoh agama, tokoh pemuda serta para pembuat kebihjakan keteladanan dalam mempertahankan dan melestarikan nilai-nilai kearifan lokal dalam kehidupan sehari-hari.
\end{abstract}

Kata Kunci: Globalisasi; Pendidikan; Strategi; Internalisasi; Nilai. 


\section{PENDAHULUAN}

Globalisasi sebuah istilah yang eksistensinya sekarang ini bukanlah suatu hal yang asing bagi semua kalangan, mulai dari golongan atas sampai golongan bawah, atau bagi negara maju sampai negara berkembang sekalipun. Artinya, dewasa ini kehidupan manusia tidak pernah lepas dari pengaruh arus globalisasi. Globalisasi tersebut merambah pada seluruh tatanan disetiap lini kehidupan manusia seperti; bidang politik, ekonomi, bisinis, komunikasi, budaya dan termasuk dalam pendidikan. Hal seperti itu menandakan bahwa globalisasi menjadi sebuah fenomena yang tidak bisa dihindari oleh siapapun dan oleh negara manapun juga.

Ketika berada pada tataran empiris praktis proses globalisasi memberikan pengaruh positif maupun negative terutama dalam sikap-perilaku, pola pikir, orientasi, bahkan penentuan kebijakan. Adanya isu-isu globalisasi ini memerlukan pemikiran ulang terhadap sistem dan kebijakan dalam pendidikan di Indonesia dan khususnya pendidikan agama. Mengingat globalisasi yang diusung kaum globalis terutama Barat prinsipnya membawa misi liberalisasi, westernisasi, terhadap negara-negara berkembang termasuk Indonesia. Untuk itu salah satu alternatif "melawan" derasnya arus glibalisasi dan dampak yang ditimbulkan tersebut adalah mempertahankan nilai-nilai luhur bangsa Indonesia sebagai budaya lokal atau lokalisasi dalam budaya. Karena ada dua kepentingan yang saling berpengaruh dalam tataran praktis, maka diperlukan konsep dan formulasi yang tegas bagaimana dalam menyikapinya, apakah perlu mengintegrasikan atau mensinergikan antara keduanya sehingga bermanfaat (mutual respect) dari kemajuan globalisasi tanpa harus meninggalkan nilainilai luhur bangsa.

Melalui pembahasan artikel ini, akan mengekplorasi bagaimana mendesain (memahami) globalisasi terhadap dunia pendidikan tersebut menjadi sebuah keniscayaan khususnya dalam pendidikan Islam. Upaya membangun ketahanan budaya Bangsa Indonesia belum menunjukkan hasil yang signifikan hingga dewasa ini. Ketahanan budaya Bangsa Indonesia masih rentan seiring dengan semakin derasnya arus persaingan bebas dunia. Hal lain yang menyebabkan rentannya ketahanan kebudayaan Indonesia adalah karena adanya disorientasi tata nilai, krisis identitas, dan rendahnya daya saing bangsa. Krisis ketahanan budaya Bangsa Indonesia merupakan indikasi dari adanya krisis identitas negeri ini. Terjadinya krisis identitas tersebut bersamaan dengan rendahnya daya saing hasil karya bangsa telah mengakibatkan semakin melemahnya rasa percaya diri dan inferioritas serta sikap ketergantungan bangsa terhadap negara lain. Kondisi ini akan lebih jauh menyuburkan sikap rendahnya apresiasi masyarakat terhadap hasil karya dan kekayaan budaya nasional Bangsa Indonesia. Di samping itu, menipisnya semangat nasionalisme tersebut juga sebagai akibat dari lemahnya kemampuan bangsa dalam mengelola keragaman yang menjadi ciri khas Bangsa Indonesia.

Ahmad Safril Mubah berpendapat bahwa upaya-upaya pembangunan jati diri bangsa Indonesia, termasuk didalamnya penghargaan pada nilai budaya dan bahasa, nilai solidartias sosial, kekeluargaan dan rasa cinta tanah air dirasakan semakin memudar. (Mubah 2011:304) Budaya lokal yang sesuai karakter bangsa semakin sulit ditemukan, sementara itu budaya global lebih mudah merusak. Potensi keanekaragaman kebudayaan yang dimiliki oleh Bangsa Indonesia seharusnya bisa lebih dioptimalkan lagi. Jangan sampai keragaman justru dijadikan sebagai ancaman terjadinya disintegrasi bangsa, apalagi di tengah persaingan dunia seperti saat ini karena dalam menghadapi pasar bebas dunia, kesatuan dan persatuan bangsa juga merupakan faktor penting 
untuk dapat memenangkan kompetisi tersebut. Tanpa kesatuan dan persatuan bangsa tersebut, negara tidak akan kuat menghadapi gempuran kebudayaan dari luar. Internalisasi kearifan lokal dapat dilakukan dengan berbagai cara, salah satunya adalah melalui pendidikan. Dwi Siswoyo menjelaskan bahwa salah satu fungsi pendidikan adalah direktif, di mana pendidikan dipandang untuk menyiapkan manusia sebagai tenaga kerja dan menyiapkan warga negara yang baik.(Siswoyo 2016:20-21).

Berdasarkan hal tersebut, pendidikan tidak bisa dipisahkan dari peran guru sebagai tenaga pengajar. Baik buruknya pendidikan berkaitan erat dengan kompetensi serta kemampuan guru selama mengajar dan sarana prasarana yang mendukung kegiatan tersebut. Sarana dan prasarana tersebut salah satunya berkaitan dengan metode serta media pembelajaran yang diterapkan. Oleh sebab itu, guru harus mengolah proses belajar mengajar yang memberikan rangsangan kepada siswa dalam kegiatan belajar. Sistem pembelajaran yang tidak bervariasi akan membuat siswa cenderung jenuh dan bosan. Keterlibatan siswa dalam proses belajar menandakan berjalannya proses belajar yang aktif. Hal tersebut perlu didorong untuk menciptakan suasana belajar yang demokratis, menarik dan menyenangkan, sehingga siswa dapat menjadi tertarik dan termotivasi untuk belajar. Internalisasi nilai-nilai kearifan lokal melalui pendidikan perlu dikemas dengan berbagai cara. Terlebih lagi saat ini tantangan dunia semakin besar dan dampak negatif globalisasi semakin berkembang di kalangan generasi muda. Dalam kajian ini, penulis tertarik untuk mengkaji cara menanamkan nilai kearifan lokal melalui pendidikan di era milenial saat ini.

\section{Internalisasi}

Internalisasi (internalization) diartikan sebagai penggabungan atau penyatuan sikap, standar tingkah laku, pendapat, dan seterusnya di dalam kepribadian. (Chaplin 2005:256). Sedangkan menurut Reber, sebagaimana dikutip Mulyana mengartikan internalisasi sebagai menyatunya nilai dalam diri seseorang, atau dalam bahasa psikologi merupakan penyesuaian keyakinan, nilai, sikap, praktik dan aturan-aturan baku pada diri seseorang. (Mulyana 2004:21). Pengertian ini mengisyaratkan bahwa pemahaman nilai yang diperoleh harus dapat dipraktikkan dan berimplikasi pada sikap. Internalisasi ini akan bersifat permanen dalam diri seseorang. Lain lagi menurut Ihsan yang memaknai internalisasi sebagai upaya yang dilakukan untuk memasukkan nilai-nilai kedalam jiwa sehingga menjadi miliknya. (Ihsan 1997:155) Jadi masalah internalisasi ini tidak hanya berlaku pada pendidikan agama saja, tetapi pada semua aspek pendidikan.

Internalisasi adalah menyatunya nilai dalam diri seseorang, atau dalam bahasa psikologi merupakan penyesuaian keyakinan, nilai, sikap, perilaku (tingkah laku), praktik dan aturan baku pada diri seseorang. (Mulyana 2004:21). Nilai-nilai agama Islam adalah nilai luhur yang ditransfer dan diadopsi ke dalam diri. Jadi, internalisasi nilai-nilai agama Islam adalah suatu proses memasukkan nilainilai agama secara penuh ke dalam hati, sehingga ruh dan jiwa bergerak berdasarkan ajaran agama Islam. Internalisasi nilai-nilai agama Islam itu terjadi melalui pemahaman ajaran agama secara utuh, dan diteruskan dengan kesadaran akan pentingnya agama Islam, serta ditemukannya posibilitas untuk merealisasikannya dalam kehidupan nyata. (Alim 2006:10).

\section{Kearifan Lokal}

Kearifan lokal merupakan suatu bentuk warisan budaya Indonesia. Kearifan lokal terbentuk sebagai proses interaksi antara manusia dengan lingkungannya dalam rangka memenuhi berbagai 
kebutuhannya. Proses-proses terbentuknya kearifan lokal sangat bergantung kepada potensi sumberdaya alam dan lingkungan serta dipengaruhi oleh pandangan, sikap, dan perilaku masyarakat setempat terhadap alam dan lingkungannya. Kearifan lokal berbeda-beda di setiap daerah dan di dalamnya terkandung berbagai norma dan nilai religius tertentu. Namun pada dasarnya proses kearifan lokal berjalan selaras dengan alam. Hal ini sesuai dengan pendapat Edmund Woga bahwa secara substantif, kearifan lokal berorientasi pada keseimbangan dan harmoni manusia, alam, dan budaya; kelestarian dan keragaman alam dan kultur; konservasi sumberdaya alam dan warisan budaya; penghematan sumberdaya yang bernilai ekonomi; moralitas dan spiritualitas. (Suyahman 2017). Di era globalisasi saat ini, banyak ditemui berbagai krisis ekologi yang muncul akibat keseimbangan alam terganggu. Tanpa kita sadari berbagai tindakan dan sikap kita telah merusak ekologi.

Penggunaan teknologi yang tidak tepat guna salah satunya dapat mengganggu keseimbangan alam seperti perubahan iklim, krisis air bersih, pencemaran udara, dan berbagai krisis ekologi lainnya. Oleh sebab itu, perlu kembali mengembangkan dan melestarikan kearifan lokal yang berkembang di masyarakat pedesaan. Adapun prospek kearifan lokal di masa depan sangat dipengaruhi oleh pengetahuan masyarakat, inovasi teknologi, permintaan pasar, pemanfaatan dan pelestarian keanekaragaman hayati di lingkungannya serta berbagai kebijakan pemerintah yang berkaitan langsung dengan pengelolaan sumberdaya alam dan lingkungan serta peran masyarakat lokal.(Suhartini 2009).

\section{METODE PENELITIAN}

Penelitian ini menggunakan jenis penelitian kepustakaan (library research).
Pendekatan penelitian adalah analisis teks dan informasi yang terkait dengan kajian. Sumber data penelitian ini adalah buku ilmiah, jurnal, hasil riset ilmiah, hasil kajian ilmiah, hasil seminar, dan sebagainya. Kaelan menyatakan bahwa, dalam penelitian kepustakaan kadang memiliki deskriptif dan juga memiliki ciri historis. (Kaelan 2010:134) Teknik pengumpulan data dilakukan dengan melakukan identifikasi wacana dari buku-buku, makalah atau artikel, majalah, jurnal, web (internet), ataupun informasi lainnya yang berhubungan dengan judul penulisan untuk mencari hal-hal atau variabel yang berupa catatan, transkip, buku, surat kabar, majalah, dan sebagainya yang berkaitan dengan kajian penelitian. Aktifitas analisis data model ini antara lain, reduksi data (data reduction), display data dan gambaran konklusi atau verifikasi (conclusion drawing/verification). Pendekatan analisis data ini adalah hermeneutika, yaitu metode pemahaman, yakni aktifitas interpretasi terhadap obyek yang mempunyai makna (meaning-full form) dengan tujuan untuk menghasilkan kemungkinan yang obyektif.(Bleicher 1980:28). Pernyataan pakar ditelaah dan diinterpretasikan terkait dengan masalah penelitian.

\section{Globalisasi dalam Pendidikan Islam}

Globalisasi atau penyejagatan, secara sederhana diartikan sebagai proses mendunia.(Departemen Pendidikan Nasional 2007:1038) Sedangkan secara utuh terkait definisi globalisasi yang diberikan nampaknya belum ada konsensius dari para ahli, sehingga ditemukan berbagai pendapat dan makna yang berbeda sesuai dengan sudut pandang yang dipergunakan. Ada yang memandangnya sebagai suatu proses sosial, atau proses sejarah, atau proses alamiah yang akan membawa seluruh bangsa dan negara di dunia makin terikat satu sama lain, dalam mewujudkan satu tatanan kehidupan baru atau kesatuan ko-eksistensi dengan menyingkirkan batas-batas 
geografis, ekonomi dan budaya masyarakat. Dalam hal ini Peter Drucker menyebutkan globalisasi sebagai zaman transformasi sosial.

Kehidupan yang berjalan saat ini penuh dengan perbagai macam problematika/permasalahan, oleh karena itu membutuhkan solusi yang dapat memberikan pencerahan ke arah yang lebih baik, salah satunya adalah aspek pendidikan. Dalam aspek pendidikan akan diajarkan bagaimana memahami dan menyelami makna esensial dalam kehidupan. Tentunya pendidikan akan memberikan sumbangsih nyata kepada peserta didik dalam membekali mereka sebagai anak bangsa yang berbudaya dan beradab.(Muhdi 2014) Terkait dengan hal tersebut khususnya pendidikan Islam memiliki prinsip yang kuat seperti yang disampaikan Athiyah al-Abrasyi dalam bukunya Al-Tarbiyah al-Islamiyah, Nata 2010:103) menurutnya pendidikan Islam merupakan pendidikan ideal, itu didasarkan pada prinsip-prinsip kebebasan dan demokrasi dalam pendidikan, pembentukan akhlak yang mulia sebagai tujuan pendidikan Islam. Tentunya manusia diberikan akal dan nurani, pendidikan Islam mewadahi dan memberikan perhatian yang baik yang dapat mengarahkan insting seseorang untuk senantiasa belajar, memahami sesuatu, memperhatikan keadaan sosialmasyarakat. Pada dasarnya pendidikan adalah hak semua orang/kalangan, tidak memandang status seseorang. Pendidikan sangat adil kepada siapapun, pendidikan tidak memberikan diskriminasi bahkan sebaliknya sangat egaliter kepada siapapun. $\mathrm{Hal}$ itulah yang sangat diapresiasi oleh Islam, maka pendidikan Islam sejatinya menyadarkan seseorang untuk senantiasa memperhatikan apa yang dinamakan long life education (Pendidikan Sepanjang Hayat).(Nata 2010:106).

Aspek lainnya dari pendidikan Islam adalah sifatnya yang inklusif (terbuka) bukan ekslusif ( tertutup). Setiap orang boleh mempelajari segala sesuatu dan boleh jadi bersifat global. Dalam hal ini bisa jadi pendidikan Islam jika dilihat secara sepihak adalah mempelajari ilmu agama saja, namun sebenarnya ketika seseorang mempelajari ilmu sebisa mungkin antara ilmu agama dan umum harus seimbang. Ilmu agama diperlukan sebagai landasan berpijak, sumber motivasi,senantiasa manusia agar berjalan lurus.(Nata 2010:108) Pendidikan Islam yang dipahami selama ini barangkali berangkat dari aspek-aspek berikut: 1) ajaran-ajaran dan nilai-nilai fundamental yang terkandung dalam sumber dasarnya yaitu al-Qur"an dan as-Sunnah. 2) Pendidikan Islam dapat dipahami sebagai pendidikan agama Islam yaitu adanya upaya mendidik agama Islam atau ajaran Islam dan nilainilainya, agar menjadi way of life ( pandangan hidup). 3) Pendidikan dalam Islam, yaitu proses dan praktik penyelenggaran pendidikan yang berlangsung dan berkembang dalam sejarah umat Islam. (Muhaimin dalam (Bakar dan Surohim 2005:6)) Sehingga dengan realitas tersebut maka implementasi pendidikan agama Islam yang spesifik dalam rangka internalisasi melalui kearifan lokal dalam menginternalisasikan nilai-nilai Islam di tengah arus globalisasi ini merupakan hal yang mutlak adanya.

Namun segenap pengaruh buruk ini dapat dieliminasi dengan meneguhkan kembali landasan-landasan religius, penguasaan keilmuan Islam, dan pembelajaran ilmu pengetahuan yang relevan dengan perkembangan ilmu pengetahuan dan teknologi.(Fadjar 1999:107-8). Disadari atau tidak, secara pasti globalisasi merupakan proses dan dinamika yang pengaruhnya telah berhasil mengebiri tradisi dan nilainilai luhur keagamaan umat Islam dewasa ini. "Dinamika modernisasi serta globalisasi telah membawa dampak yang cukup serius dalamtatanan kehidupan umat beragama, khususnya bagi agama Islam. (M. Nasir Budiman dalam (Budiman 2008)). 


\section{PEMBAHASAN}

\section{Globalisasi terbadap Pendidikan Islam}

Dalam menjalani kehidupan, manusia tidak akan lepas dari kegiatan pendidikan, baik pendidikan dalam bentuk fisik maupun psikis.(Syaefuddin 2005:9). Pendidikan merupakan sistem dan cara meningkatkan kualitas hidup manusia dalam segala aspek kehidupan manusia. Dalam sejarah umat manusia, hampir tidak ada kelompok manusia yang tidak menggunakan pendidikan sebagai alat pembudayaan dan peningkatan kualitasnya.(Sanaky 2003:4). Pendidikan Islam merupakan sebuah pendidikan yang harus dilakukan secara sadar untuk mencapai tujuan yang jelas melalui syariat Islam. Pendidikan Islam berlaku universal dan hendaknya diarahkan untuk menyadarkan manuia bahwa diri mereka adalah hamba Tuhan yang berfungsi menghambakan kepada-Nya. Jadi tujuan pendidikan Islam adalah menyadarkan manusia agar dapat mewujudkan penghambaan diri kepada Allah SWT, baik secara sendiri-sendiri maupun secara bersama-sama. Dengan demikian, konsep pendidikan Islam tidak boleh dan tidak dipisahkan dari konsepsi Ketuhanan.

Pendidikan agama mempunyai peranan sangat penting, sebab pendidikan agama merupakan bekal yang kuat untuk dijadikan pondasi untuk membangun sumber daya manusia yang berkualitas. Peningkatan SDM akan mencapai kualitasnya, jika peranan pendidikan agama dan tuntunan yang benar diposisikan pada tempatnya, karena pendidikan agama sebagai kendali mesin dalam suatu kehidupan membentuk manusia yang manusiawi dan berakhlakul karimah. Untuk mengatasi masalah tersebut di atas, pendidikan agama (Islam) mempunyai posisi yang penting, karena pendidikan agama sebagai sarana pembentukan dan pembangunan pondasi manusia Indonesia yang mempunyai nilai etik, moral, berkepribadian dilandasi dengan iman dan bertaqwa, dapat dijadikan sebagai pengendali dan dapat mengokohkan jiwa. Dengan kendali yang kokoh akan menghasilkan individuindividu yang berpegang kuat dengan AlQur"an dan Al-Hadits sebagai pegangan setiap pribadi yang berakhlakul karimah. Tujuan pendidikan agama pada intinya adalah mencari kebahagiaan dunia dan akhirat secara seimbang. Begitu pula halnya dengan tujuan pendidikan agama Islam di perguruan tinggi adalah untuk menginternalisasi ajaran Islam yang pada peserta didik dalam menjalani kehidupan sehari-hari agar mereka memahami dan menghayati nilai-nilai ajaran Islam.

Dalam pembelajaran Pendidikan Agama Islam (PAI) yang menjadi tujuan utamanya adalah bagaimana nilai-nilai ajaran Islam yang diajarkan akan dapat tertanam dalam diri siswa sehingga terjadi perubahan tingkah laku yang dilandasi dengan nilai-nilai ajaran Islam dalam kehidupan pribadinya maupun kehidupan sosial yang nantinya dapat berdampak pada terbentuknya "insan kamil", bukan pemahaman bahwa proses pembelajaran PAI hanya sebagai proses "penyampaian pengetahuan tentang agama Islam" seperti yang terjadi selama ini. Internalisasi (internalization) diartikan sebagai penggabungan atau penyatuan sikap, standar tingkah laku, pendapat, dan seterusnya di dalam kepribadian.(Chaplin 2005:256). Sedangkan menurut Reber, sebagaimana dikutip Mulyana mengartikan internalisasi sebagai menyatunya nilai dalam diri seseorang, atau dalam bahasa psikologi merupakan penyesuaian keyakinan, nilai, sikap, praktik dan aturanaturan baku pada diri seseorang.(Mulyana 2004:21).

Pengertian ini mengisyaratkan bahwa pemahaman nilai yang diperoleh harus dapat dipraktikkan dan berimplikasi pada sikap. Internalisasi ini akan bersifat permanen dalam diri seseorang. Lain lagi menurut Ihsan yang memaknai internalisasi sebagai upaya yang dilakukan untuk 
memasukkan nilai - nilai kedalam jiwa sehingga menjadi miliknya.(Ihsan 1997:155). Jadi masalah internalisasi ini tidak hanya berlaku pada pendidikan agama saja, tetapi pada semua aspek pendidikan, pada pendidikan pra-sekolah, pendidikan sekolah, pendidikan menengah, pendidikan tinggi dan sebagainya. Dalam kaitannya dengan nilai, pengertian pengertian yang diajukan oleh beberapa ahli tersebut pada dasarnya memiliki substansi yang sama. Dengan demikian penulis menyimpulkan bahwa internalisasi sebagai proses internalisasi nilai kedalam jiwa seseorang sehingga nilai tersebut tercermin pada sikap dan prilaku yang ditampakkan dalam kehidupan sehari - hari (menyatu dengan pribadi). Suatu nilai yang telah terinternalisasi pada diri seseorang memang dapat diketahui ciri-cirinya dari tingkah laku.

Oleh karena itu menurut Ahmad Tafsir, pendidikan dalam Islam adalah orang-orang yang bertanggung jawab terhadap perkembangan anak didik dengan mengupayakan perkembangan seluruh potensi anak didik baik potensi efektif, potensi kognitif maupun potensi psikomotorik.(Tafsir 1992:74-75). Oleh karena itu hakekat pendidikan Islam adalah "usaha orang dewasa muslim yang bertaqwa secara sadar mengarahkan dan membimbing pertumbuhan serta perkembangan fitrah (kemampuan dasar) anak didik melalui ajaran Islam ke arah titik maksimal pertumbuhan dan perkembangannya."(M. Arifin 1991:32). Jadi, jelaslah bahwa proses pendidikan merupakan rangkaian usaha membimbing, mengarahkan potensi hidup manusia yang berupa kemampuankemampuan dasar dan kemampuan belajar, sehingga terjadilah perubahan di dalam kehidupan pribadinya sebagai makhluk individual dan sosial serta dalam hubungannya dengan alam sekitar di mana ia hidup. Proses tersebut harus senantiasa berada di dalam nilai-nilai Islami, yaitu nilai-nilai yang melahirkan norma-norma syari"ah yang sesuai dengan pendidikan Islam. Tugas pendidikan Islam selanjutnya adalah mewariskan nilai-nilai Islam. Hal ini dikarenakan nilai-nilai Islam akan mati bila nilai-nilai dan norma-norma agama tidak berfungsi dan belum sempat diwariskan ke generasi berikutnya.

Nilai-nilai Islam dan peradaban tidak dapat dipisahkan dengan kelahiran Islam itu sendiri. Maka dari itu lembagalembaga pendidikan memiliki tugas selain mengembangkan perolehan pengalaman, lembaga pendidikan harus mampu mengupayakan perolehan pengalaman generasi terdahulu melalui transfer tradisi. Islam mengemban tugas menghidupkan kembali tradisi, konsep keagamaan dan mewariskan ilmu-ilmu yang diperoleh dari kitab- kitab lama ke generasi selanjutnya. Islam yang hendak diwujudkan dalam perilaku manusia melalui proses pendidikan, bukanlah semata-mata sistem teologinya saja, melainkan lebih dari itu yaitu termasuk peradabannya yang lebih sempurna. Oleh karena itu "Islam berhadapan dengan segala bentuk kemajuan dan modernisasi masyarakat, tidaklah akan mengalami kesulitan mengingat wataknya yang lentur dal am menghadapi perkembangan kebudayaan manusia."(M. Arifin 1991:38). Oleh karena itu kebudayaan Islam haruslah mencerminkan nilai-nilai akhlakul karimah dan menjadi bagian dari ibadah sebagai wujud kerja sama kreatif antara Allah dan manusia sebagai hamba-Nya di muka bumi. "Nilai-nilai kebudayaan adalah pencapaian nilai spiritual yang memperkaya kehidupan batin manusia".

Selanjutnya, proses globalisasi terjadi dalam tataran dunia pendidikan, yaitu adanya komersialisasi pendidikan. Pendidikan dijadikan ajang berkompetisi meraih yang terbaik dalam mendapatkan pengakuan masyarakat global, padahal hakikatnya kompetisi tersebut mengorbankan etika moral yang berlaku di masyarakat lokal khususnya Indonesia. Dalam hal ini menimbulkan persaingan 
yang tidak sehat dan membuat permasalahan baru, yaitu menciptakan kesenjangan yang sangat jauh antara miskin dan kaya terutama dalam memperoleh kesempatan yang sama didalam memperoleh pendidikan. Tidak dipungkiri pula, kompetisi global tersebut hakikatnya dominan pada sikap berpikir pragmatis dengan indikator keberhasilan seseorang mengedepankan kemampuan prestasi akademik (kecerdasan intelektual) semata, dan jauh dari nilai-nilai etika moral atau agama (kecerdasan spiritual dan emosional) termasuk didalamnya unsur kejujuran, keadilan, sopan-santun menjadi terabaikan.

Untuk itu, walaupun globalisasi adalah sebuah keniscayaan diperlukan sebuah kekuatan budaya bangsa agar tidak terombang-ambing dalam dinamika yang tidak dapat diprediksikan ke mana arahnya. Budaya lokal atau kearifan lokal dijadikan alternatif dan menjadi penyeimbang (balance) dan counter-discourse terhadap lajunya arus globalisasi, khususnya masyarakat Indonesia.

\section{Strategi Internalisasi Nilai-Nilai Kearifan Lokal dalam Pendidikan Islam Di Era Globalisasi}

Proses pendidikan pada prinsipnya adalah bagaimana menyiapkan anak didik tangguh dengan sikap mental dan kuat yang dilandasi nilai-nilai luhur bangsa, sehingga dapat berperan dan menyesuaikan diri dalam lingkungan masyarakatnya. Mengingat tantangan dunia pendidikan khususnya pendidikan Islam saat ini sangat kompleks, disatu sisi berhadapan dengan kemajuan globalisasi atau era sain teknologi komunikasi dan disisi lain harus mempertahankan nilai-nilai lokal bangsa. Maka, disinilah diperlukan kearifan dan kebijakan bagaimana mempersipkan anak didik yang mampu bertahan (survive) menghadapi arus globalisasi. Dengan kekuatan tersebut paling tidak menjadi modal dasar sebagai bangsa bermartabat yang tidak terlepas dari akar budaya dan nilai-nilai luhur bangsa (lokalisasi). Walaupun akhirnya harus mengakomodasi kemajuan globalisasi, namun tanpa harus meninggalkan jati diri bahkan terbawa arus dampak negatif yang diakibatkannya.

Dalam konteks ini pernah diungkapkan Khaerudin Kurniawan, bahwa globalisasi menjadi sebuah tantangan satu diantaranya muncul invasi dan kolonialisme baru dalam Iptek.(Kurniawan 1999). Artinya, pendidikan Islam dalam konsep ini berperan sebagai instrumen paling ampuh dalam menyaring budaya-budaya yang kurang baik khususnya Barat serta dampak yang diakibatkan globalisasi tersebut, dan sekaligus menguatkan budaya lokal sebagai identitas bangsa. Dengan demikian bagaimana seharusnya menyiapkan sumber daya manusia berakhlak mulia yang memiliki daya saing tinggi (qualified) tangguh, bertahan (survive), dan dapat berperan aktif dalam dunia global tanpa harus melapasakan identitas diri sebagai bangsa yang bermartabat. Strategi internalisasi kearifan lokal Indonesia dapat dilaksanakan melalui proses pembelajaran di sekolah. Hal tersebut dapat dilaksanakan melalui kegiatan pembelajaran. Salah satunya adalah mengintegrasikannya dengan pembelajaran pendidikan Islam. Dalam praktinya memerlukan sinergi dari tiga unsur utama dalam pendidikan. Unsur tersebut terdiri dari pendidik atau guru, peserta didik atau siswa, dan juga tujuan pendidikan. Ketika unsur tersebut dipandang penting untuk bekerja bersama karena ada sebuah kesinambungan antara tiap unsur yang tidak dapat terlepaskan.(Fajarini 2014).

Guru memiliki peran yang besar dalam internalisasi nilai kearifan lokal Indonesia melalui kegiatan pembelajaran, khususnya pembelajaran pendidikan Islam. Akan tetapi, pembelajaran pendidikan Islam yang bertujuan untuk menanamkan nilai kearifan lokal memiliki beberapa masalah yang sifatnya konseptual seperti penyajian bahan pembelajaran dalam kurikulum yang disusun menjadi metode pembelajaran belum efektif. Materi 
pembelajarannya diasumsikan berbasis hafalan sedangkan ada beberapa materi yang dapat dibuat dengan peta konsep sehingga mempermudah siswa. Hal tersebut tentu dilatarbelakangi oleh proses pembelajaran yang kurang memotivasi siswa untuk mengikuti kegiatan belajar. Pengembangan layanan berupa mutu pembelajaran dari guru dituntut memiliki kemampuan dan keterampilannya secara profesional. Sehubungan dengan hal tersebut, penyajian metode pembelajaran harus sesuai dan dapat diterima oleh siswa dengan memperhatikan karakteristik siswa.

Di samping penerapan metode yang sesuai dengan karaktersitik siswa, guru dapat mencari atau membuat sumber belajar, bahan ajar, atau media pembelajaran yang tepat untuk menjawab permasalahan seperti yang dikemukakan di atas. Untuk menanamkan nilai kearifan lokal yang benar dan baik kepada peserta didik, maka peran guru sebagai perencana dan pengelola pembelajaran dituntut untuk lebih meningkatkan kemampuan professional mengajar. Untuk menciptakan suasana belajar yang menunjang proses pembelajaran serta mampu mengupayakan siswa terlibat secara aktif pada saat proses pembelajaran berlangsung. Namun, kebanyakan yang terjadi di lapangan adalah proses pembelajaran masih terjebak pada proses indoktrinisasi yang mengakibatkan siswa hanya terpaku pada kegiatan menghafal materi sehingga kemampuan yang disentuh hanyalah kemampuan berfikir tingkat rendah. Sedangkan yang diharapkan pada proses pembelajaran sejarah memerlukan keterlibatan siswa secara aktif untuk mengembangkan kemampuan berfikir kritis analisis agar proses pembelajaran tersebut dapat mengembangkan kemampuan berfikir kritis siswa.(Wandari 2015).

Melihat praktek pembelajaran di atas, maka guru harus mencari atau membuat sumber belajar, bahan ajar, dan media pembelajaran yang tepat untuk menjawab permasalahan tersebut. Guru perlu sumber belajar, bahan ajar, dan media pembelajaran yang dapat membuat mata pelajaran sejarah menjadi mata pelajaran yang menarik dan tidak membosankan. Selain itu, guru juga harus memfasilitasi siswa untuk bisa belajar sejarah dengan menggunakan tingkat berfikir kritis. Agar pembelajaran itu menarik dan siswa dapat berfikir kritis, maka guru harus melibatkan siswa secara langsung dalam pembelajaran. Hal ini dilakukan agar siswa tertarik dan tertantang untuk mengikuti pelajaran tersebut. Dengan adanya ketertarikan dan tantangan tersebut, maka siswa akan aktif mengikuti proses pembelajaran. Keaktifan siswa dalam pembelajaran sejarah ini salah satunya dapat ditentukan oleh media yang digunakan oleh guru. Salah satunya bias berbentuk educational games.Di samping itu, diharapkan adanya sebuah sumber belajar, bahan ajar, dan juga media pembelajaran yang telah memperhatikan dan menerapkan sebuah bentuk teori efektifitas pemanfaatan media pembelajaran yaitu dengan menggunakan teori kerucut pengalaman belajar yang disampaikan oleh Edgar Dale. Teori tersebut menjelaskan suatu hasil belajar adalah hasil yang diawali dengan pengalaman langsung, benda tiruan, hingga lambang verbal yang bersifat abstrak, dan di puncak kerucut akan semakin abstrak terkait media tersebut. Hal tersebut disampaikan oleh Arsyad pesan semakin abstrak bila hanya disampaikan dengan kata atau lambang saja, dibanding menggunakan menggunakan media.(Kurniawan dan Toharudin 2017).

\section{KESIMPULAN}

Beberapa uraian dan penjelasan yang dipaparkan terkait dengan globalisasi dalam pendidikan Islam dapat disimpulkan, globalisasi sebagai proses mendunia dipahami sebagai westernisasi, liberalisasi, bahkan kolonialisasi modern yang dilakukan Barat terhadap bangsa berkembang di dunia. Dengan semangat 
hemogenitas tunggal menjadikan batas dunia menjadi hilang, melintasi budaya, ekonomi, politik, pendidikan dan lainnya. Karena itu tidak jarang globalisasi menimbulkan dampak negatif bagi kehidupan suatu masyarakat.

Salah satu alternatif sebagai bottom up terhadap lajunya golabalisasi adalah pentingnya merumuskan strategi internalisasi nilai kearifan lokal detengah terpaan arus globalisasi, yang dipahami sebagai sebuah counter discourse, yaitu mengusung kekuatan dari dalam atau kemampuan mengusung nilai-nilai budaya lokal bangsa yaitu nilai-nilai Pancasila. Dalam hal ini ditempuh dan kerja sama secara massif melibatkan seluruh elemen masyarakat dan bangsa sesuai dengan kapasitas dan kapabilitas dimiliki, termasuk didalamnya unsur budaya, agama, dan negara.

Ketika dalam tataran praktis empiris lokalisasi sebagai upaya "melawan" arus globalisasi yang ditempuh dengan strategi penguatan dari dalam untuk bertahan (survive), yaitu dengan penguatan pendidikan nilai-nilai Ilahi yang akhirnya dapat melahirkan akhlak mulia, pendidikan kewarganegaraan seni-budaya. Pendidikan sain dan teknologi salah satu bentuk apresiasi melalui proses adopsi dalam pendidikan terhadap nilai positif globalisasi. Konsep atau jargon "almuhafazah "ala al-qadim al-shalih wa 'l akbad bi'l jadid al-aslah" (memelihara yang lama baik, dan mengambil yang baru yang lebih baik) inilah dijadikan sebagai landasan dalam bertindak.

\section{DAFTAR PUSTAKA}

Alim, Muhammad. 2006. Pendidikan Agama Islam Upaya Pembentukan Pemikiran dan Kepribadian Muslim. Bandung: Remaja Rosdakarya.

Bakar, Usman Abu, dan Surohim. 2005. Kerangka Konseptual Pembaharuan Pendidikan Islam. Yogyakarta: Safiria
Insania Press.

Bleicher, Josef. 1980. Contemporary Hermeneutics: Hermeneutics as Method, Philosophy and Critique. London: Routledge.

Budiman, M. Nasir. 2008. Kompilasi Pemikiran Guru Besar LAIN ArRaniry. Banda Aceh: Ar-Raniry Press.

Chaplin, J. .. 2005. Kamus Lengkap Psikologi. Jakarta: Raja Grafindo Persada.

Departemen Pendidikan Nasional. 2007. Kamus Besar Bahasa Indonesia Pusat Bahasa. Jakarta: Departemen Pendidikan Nasional.

Fadjar, Malik. 1999. Reorientasi Pendidikan Islam. Jakarta: Fajar Dunia.

Fajarini, Ulfah. 2014. "PERANAN KEARIFAN LOKAL DALAM PENDIDIKAN KARAKTER." Sosio Didaktika Social Science Education Journal 1(2):123-30. doi: 10.15408/sd.v1i2.1225.

Ihsan, Fuad. 1997. Dasar-dasar Kependidikan. Jakarta: Rineka Cipta.

Kaelan. 2010. Metode Penelitian Agama Kualitatif Interdisipliner. Yogyakarta: Paradigma.

Kurniawan, Iwan Setia, dan Uus Toharudin. 2017. "Values of Local Wisdom: A Potential to Develop an Assessment and Remedial." International Journal of Evaluation and Research in Education (IJERE) 6(1):71-78. $\quad$ doi: 10.11591/ijere.v6i1.6349.

Kurniawan, Khaerudin. 1999. "Arah Pendidikan Nasional Memasuki Milenium Ketiga." Suara Pembaharuan.

M. Arifin. 1991. Ilmu Pendidikan Islam Suatu Tinjauan Teoritis dan Praktis Berdasarkan Pendekatan Interdisipliner. Jakarta: Bumi Aksara.

Mubah, A. Safril. 2011. "Strategi Meningkatkan Daya Tahan Budaya Lokal dalam Menghadapi Arus Globalisasi." Demokrasi Ei era Digital 24(4):303. 
Muhdi. 2014. "Posisi Mata kuliah PAI Dalam Kurikulum Perguruan Tinggi Umum." Jurnal INTEKN $A$ Tahun XIV(1):1-101.

Mulyana, Rohmat. 2004. Mengartikulasikan Pendidikan Nilai. Bandung: Alfabeta.

Nata, Abuddin. 2010. Ilmu Pendidikan Islam. Jakarta: Prenadamedia Group.

Sanaky, Hujair A. H. 2003. Paradigma Pendidikan Islam: Membangun Masyarakat Madani Indonesia. Yogyakarta: Safiria Insania Press.

Siswoyo, Dwi. 2016. Ilmu Pendidikan. Yogyakarta: UNY Press.

Suhartini. 2009. "Kajian Kearifan Lokal Masyarakat dalam Pengelolaan Sumber Daya Alam dan Lingkungan." Hal. 206-18 in Prosiding Seminar Nasional Penelitian, Pendidikan dan Penerapan MIPA, Fakultas MIPA, Universitas Negeri Yogyakarta, $16 \quad$ Mei 2009.
Yogyakarta.

Suyahman. 2017. "Internalisasi Kearifan

Lokal Dalam era Global Menyongsong Generasi Emas Tahun 2045." PIBSI XXXIX 1214-26.

Syaefuddin, A. 2005. Percikan Pemikiran Imam al-Gharali dalam Pengembangan Pendidikan Islam Berdasarkan Prinsip al-Quran dan As-Sunnah. Bandung: CV Pustaka Setia.

Tafsir, Ahmad. 1992. Ilmu Pendidikean Dalam Perspektif Islam. Bandung: Remaja Rosdakarya.

Wandari, M. 2015. "Pengembangan SMADAM (Smart Media based on Nasionalism) Berbasis Adobe Flash Interaktif untuk Meningkatkan Pemahaman dalam Pelajaran Pendidikan Kewarganegaraan SMP." 